Soviet Union's technology could adapt

President Reagan's ploy to stop or delay the supply of Siberian natural gas to Western Europe may all be in vain because of two simple technical options open to the Soviets.

Reagan's tactics have been to urge European steel manufacturers - particularly West Germany - to stop supplies of the large-diameter $(1.42 \mathrm{~m})$ steel pipe needed for the line; and to forbid General Electric and other American suppliers from shipping key parts (for example turbine blades) to Western manufacturers making the gas turbines and compressors needed to pump the gas.

But the Soviet Union is experimenting with increasing the pressure of gas in the line from its nominal 75 atmospheres to 100 or even 120 atmospheres. At 100 atmospheres, the pipeline could be built with only two parallel pipes (the current design has three) and yet carry the same net flow of gas (40,000 million standard $\mathrm{m}^{3}$ a year). At 120 atmospheres, only one pipe would be needed, according to official reports in the newspaper Pravda. This would reduce the steel requirements for the line to within the capacity of Soviet industry (although the higher pressure pipes would have to be reinforced), and it would also drastically reduce the cost.

Another neglected fact is that the design capacity of the line is in excess of the contracts for gas so far signed in Europe. Since the power required to pump gas down a pipeline rises more than linearly with the rate of gas pumped, it would be possible for the Soviets to pump the contracted gas with many fewer than the 125 gas turbines of $25 \mathrm{MW}$ currently on order in Europe. The 125 turbines are only necessary to pump the full design flow rate.

Exactly how many turbines the Soviet Union would need to be in place by $1984-$ when the line is supposed to come on stream - depends on the detailed characteristics of the line. However, the plan is to supply just 15,000 million $\mathrm{m}^{3}$ at that date - under 40 per cent of capacity. It was never envisaged that the line would be pumping its full capacity before 1987 .

In fact, according to British pipeline engineers, it would be presumptuous to assume that the Soviets would need as much as $15 / 40$ of design pumping power by 1984 , that is 47 or so $25-\mathrm{MW}$ turbine and compressor sets.

It happens that there are parts available in Europe to supply 23 such sets to the Soviet Union, six at John Brown in
Scotland and the rest in France and Italy. That would leave the Soviet Union with at most 24 sets to supply from its own industry in Leningrad, as opposed to the 102 apparent from the design. According to British turbine manufacturers, the General Electric turbines are not particularly sophisticated technology - they are based on 1950s steam turbine design. The obstacle to their manufacture in the Soviet Union is primarily a matter of industrial capacity.

At present, the Soviet Union has no such capacity for 25-MW sets, but West European engineers are convinced that a working prototype is now under test in Leningrad. According to Soviet sources this prototype is "even more efficient" than the General Electric sets it is designed to replace. Whether the Leningrad works could supply 24 of these sets in working order by 1984 is open to question, but the target is a good deal more realistic than the 102 that the Reagan embargo apparently implied.

Another option open to the Soviet Union is to divert 10-MW set production, for which it has capacity, from the six national pipelines under construction. And

\section{EPA holds out against lead}

\section{Washington}

The US Environmental Protection Agency (EPA) stuck to its guns last week and issued a regulation tightening limits on lead in gasoline, despite pressure from the Office of Management and Budget (OMB) to back off.

The new rule, to take effect on 1 November, limits the lead content of leaded gasoline to 1.1 grammes per gallon. EPA estimates that after eight years, airborne lead concentrations will be 31 per cent lower than they would be without the new rule.

Under current regulations, refiners are allowed to average the lead content of all their gasoline, both leaded and unleaded; that pool average must not exceed 0.5 grammes per gallon. But as a result, refiners have been increasing the lead content of leaded fuel (which cannot be used in new cars with catalytic converters) as demand for it drops off. Adding lead is the cheapest way of increasing octane ratings, and EPA has found refiners using as much as $\mathbf{2}$ grammes of lead per gallon.

Earlier this year, EPA had proposed relaxing the lead regulations. This was done at the bidding of Vice President George Bush's task force on regulation. But in the face of a storm of protest - and convincing evidence that reductions to date in airborne lead have brought about real reductions in blood-levels - EPA went back to the drawing board.

By the beginning of August, EPA had in Europe, the French company AlsthomAtlantique has the capacity to build complete turbines (albeit under licence from General Electric, and so in defiance of the Reagan embargo and so in risk of penalties in America).

Thus it seems entirely conceivable that one way or another the Soviet Union will meet its 1984 deadline - and that it could develop the capacity to bring the line up to full flow by 1987 , as Soviet sources continually affirm.

The pipeline design requires three 4,500 $\mathrm{km}$ strings to bring the gas from Siberia to the Western border of the Soviet Union. So far, $2,700 \mathrm{~km}$ of pipe have been delivered to the pipeline builders, according to the Soviet news agency Tass. Some $500 \mathrm{~km}$ of pipe have been welded into a single line, says Tass, and by mid-August $250 \mathrm{~km}$ had been laid in place.

Pipe laying equipment which was to have been supplied by the American Caterpillar company is also embargoed, but a new Soviet-designed pipe-layer is now under test, says Tass. The Japanese company Komatsu is also substituting for Caterpillar equipment, according to the news agency.

Robert Walgate and Vera Rich

completed its about face, and in an apparent attempt to out-flank OMB, leaked its new, tougher proposal to the New York Times. OMB nonetheless responded by requesting EPA to reconsider the proposed 1.1 gramme limit but EPA has held its ground.

OMB did get its way, however, over the issue of the so-called small refiners.

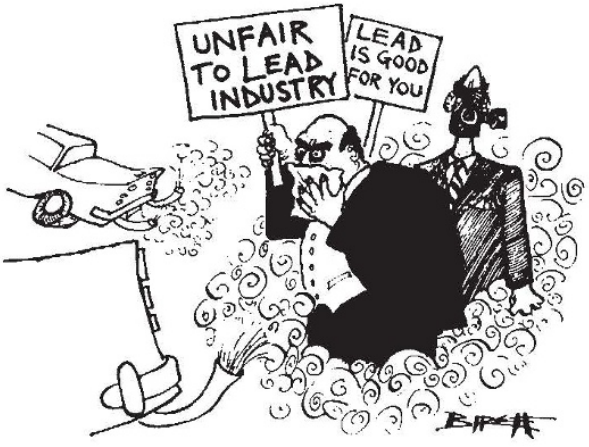

Current regulations grant an exemption for refiners who produce less than 50,000 barrels per day; they are allowed to add from 0.8 to 2.65 grammes of lead per gallon, according to their scale of production. The new rules will narrow the exemption, reserving the "small refiner" designation for producers of less than 10,000 barrels a day who were in business before October 1976. According to EPA, this will leave only 74 companies in this category, about half the current number. They will be allowed to add up to 2.5 